\title{
85. Aegirite-Augite Glaucophane Quartz Schist from the Province of Teshio, Hokkaidô, Japan.
}

By Jun Suzuki.

Department of Geology and Mineralogy, Hokkaidô Imperial University, Sapporo. (Comm. by H. YABE, M.I.A., July 13, 1931.)

1) It has been well known for a long time that gravel deposits on the river beds of certain rivers in Hokkaidô occasionally have fairly many pebbles of metamorphic rocks, mostly crystalline schists in great varieties. ${ }^{1)}$ The writer has recently had an opportunity by the favour of Professor H. Yabe of the Tôhoku Imperial University to examine microscopically the many river pebbles of glaucophane schists from the province of Teshio. The samples are all collected by Mr. K. Nishikawa from the middle course of river Obirashibe, which empties its water into the Japan Sea at a little north of the town Rumoe. In the course of microscopical study of these samples, the writer found a small block of quartz schist which is especially interesting by having aegirite-augite and glaucophane as essential components.

2) The aegirite-augite glaucophane quartz schist to be shortly described is distinctly schistose in texture and appears as a whole dark bluish grey in colour, though, more in detail, consisting of dark bluish grey and light grey layers in alternation. Being fine and compact, its individual minerals are not discernible by naked eyes. Under the microscope, it is found that the schistosity the rock reveals is due to successive layers of different mineralogical composition:-thin layers composed in most part of quartz and felspar grains which are somewhat elongated in one direction, and those rich in glaucophane and aegirite-augite which are arranged subparallel to the plane of schistosity (Fig. 1).

Quartz is the most dominant mineral in this rock, occurring as irregular minute grains with rugged outlines in a mosaic aggregate. The grains are $0.1 \mathrm{~mm}$. in average length and have their longer diarneter generally parallel to those of glaucophane and aegirite-augite. Most of the quartz grains are clear and in places they show more or less undulatory extinction.

Glaucophane is the next important constituent to quartz; its crystals

1) K. Jimbo: General Geological Sketch of Hokkaido with Special Reference to the Petrography (1892), p. 5.

H. Hachiya: Glaucophane Rocks from Obirashibe, Teshio, Hokkaido (in Japanese). Jour. Geol. Soc. Tokyo, Vol. 9 (1902), p. 98 \& 147. 


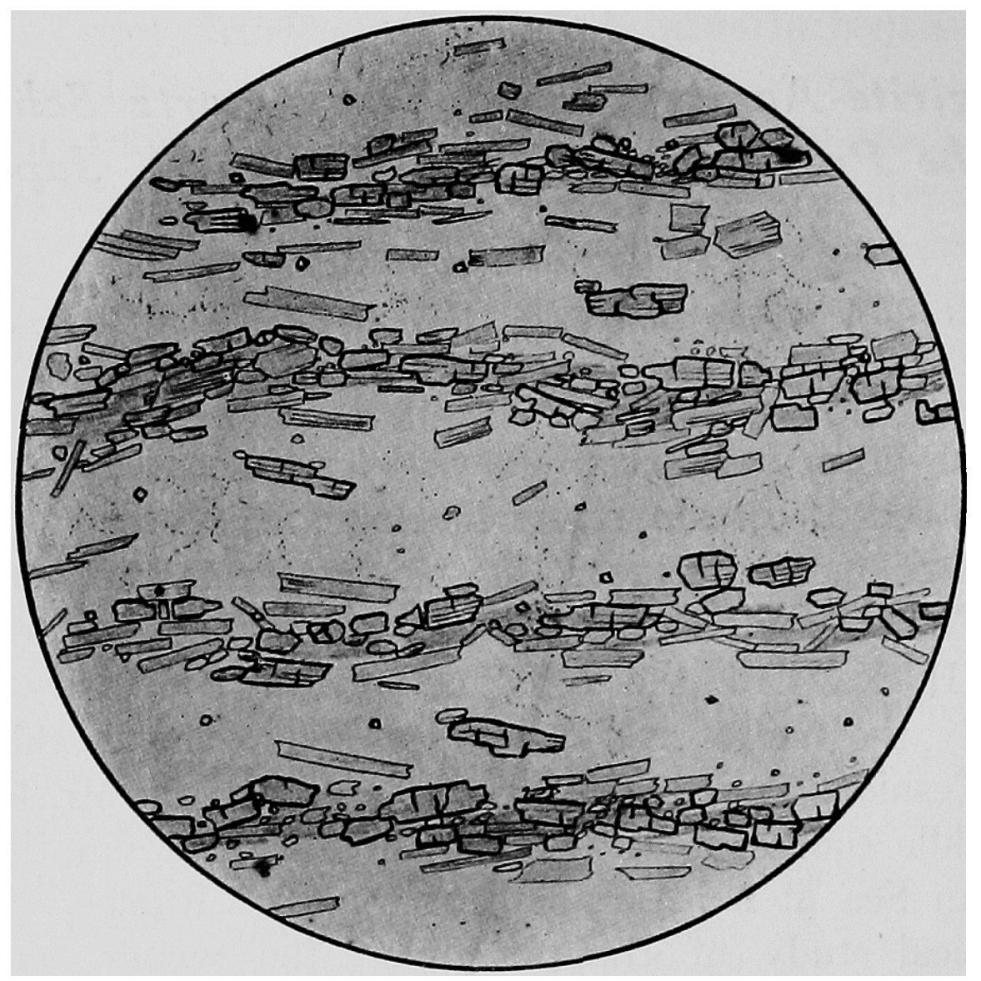

Fig. 1. $\times 100$.

Section normal to the plane of schistosity, in transmitted light; parallel nicols.

assume minute prismatic forms and are usually arranged, together with aegirite-augite prisms, parallel to the rock flowage. Larger crystals are $0.1-0.3 \mathrm{~mm}$. long. Extinction angle $c: Z$ is nearly $5^{\circ}$. It is characterised by its comparatively strong pleochroism, $X=$ light yellowish violet, $Y=$ light bluish violet and $Z=$ blue ; $Z>Y>X$.

Aegirite-augite has a short prismatic form, average length of the crystals being $0.1 \mathrm{~mm}$. Prismatic cleavage is well developed and there are seldom traces of imperfect cracks generally at right angles to the $c$-axis. The crystals are frequently broken and irregular in outline. Maximum extinction angle measured from the prism axis, $c: X$, is $25^{\circ}$. Pleochroism is strong, with the following axial colours: $X=$ grass green, $Y$ =yellowish green and $Z$ =yellowish brown; absorption is $X>Y>Z$. The crystals are usually arranged parallel to the glaucophane prisms.

Felspar is found interstitially in a comparatively small amount among the quartz grains; it is distinguished from quartz by its optical biaxiality and lower refringence. $2 \mathrm{~V}$ is nearly $75^{\circ}$ and optical character positive; hence albite. It shows frequently multiple twinning after the albite law; zonal structure is not prominent in most crystals. Garnet occurs in very minute grains, $0.01 \mathrm{~mm}$. in average, and is 
usually well shaped after a rhombic dodecahedral form. It is almost colourless and isotropic, showing a very high index of refraction.

3) The following chemical analysis of the aegirite-augite glaucophane quartz schist is by Mr. A. Kannari of the Department of Geology and Mineralogy, Hokkaidô Imperial University.

\begin{tabular}{|c|c|c|c|}
\hline $\mathrm{SiO}_{2} \ldots \ldots$ & 85.80 , & $\mathrm{TiO}_{2} \ldots . .$. tr. & $\mathrm{Al}_{2} \mathrm{O}_{3} \ldots \ldots \ldots .2 .73$ \\
\hline $\mathrm{Fe}_{2} \mathrm{O}_{3} \ldots \ldots$ & 1.70 & $\mathrm{FeO} \ldots . . .2 .60$, & $\mathrm{MnO} \ldots \ldots \ldots . .28$ \\
\hline $\mathrm{MgO} \ldots .$. & 3.00 & $\mathrm{CaO} \ldots . . .1 .20$, & .... 1.90, \\
\hline $\begin{array}{r}\mathrm{K}_{2} \mathrm{O} \\
\text { Tota }\end{array}$ & $\begin{array}{c}0.86 \\
100.5\end{array}$ & $\begin{array}{r}\mathrm{P}_{2} \mathrm{O}_{5} \ldots \ldots .0 .31,0.31, \\
\text { Snecific gra }\end{array}$ & Ignition loss 0.1 \\
\hline
\end{tabular}

This analysis includes several criteria available for determining the sedimentary origin of the rock, closely approaching to those of chert or siliceous shale. It is noticeable that the rock has a higher value of alkali than alumina in molecular proportion. It may safely be asserted that the chemical composition of its original rock stands in an intimate causal relationship with the new formation of soda-rich minerals, such as glaucophane, aegirite-augite and albite in the metamorphosed product, which judged on its mineralogical and chemical composition may belong to the group of "Alkaligneisses" of Grubenmann. ${ }^{1 \prime}$

In chemical composition, this aegirite-augite glaucophane quartz schist is similar to sericite quartz schist and glaucophane schists of the Sanbagawa (Crystalline Schists) System ${ }^{2}$ in Shikoku and other parts of Japan. In the latter rocks, however, the relative amount of alkali and alumina is always reversed as in the former.

4) Up to the end of the nineteenth century, aegirite (acmite) and aegirite-augite were known as constituent minerals of ignerous rocks only, ${ }^{3)}$ and had never been recorded as a component of metamorphic rocks. Since C. Palache ${ }^{4}$ found aegirite in a granulite of Gloggnitzer Berg, Austria, and M.A. Lacroix ${ }^{5)}$ acmite in a calcareous schist of

1) U. Grubenmann: Die Kristallinen Schiefer, (1910), p. 230.

2) J. Suzuki: Petrological Study of the Crystalline Schist System of Shikoku, Japan. Jour. Fac. Sci, Hokkaido Imp. Univ. Series IV, Vol. I, No. 1, p. 86.

3) F. Zirkel states in his text-book: "Den kristallinischen Schiefern fehlen diese Mineralien (Aegirin und Akmit), soweit bekannt, gäzlich." (Lehrbuch der Petrographie, 3 Aufl. 3, Leipzig (1894), S. 293) and C. Hintze says: "Akmit auf Eruptivgesteine beschräkt; in Elaeolithsyenit; in natronreichen Syeniten und Graniten. (Handbuch der Mineralogie, Zweiter Band (1897), 1129).

4) C. Palache: Ueber ein neues Vorkommniss des Riebeckites. Neues Jahrbuch, 1 (1895), p. 100.

5) M. A. Lacroix: Sur la constitution minéralogique de l'ile de Polycandros (Archipel). Compte Rendu, 124 (1897), p. 628. Lacroix says in his paper as: cést la premiere fois qu'un pyroxéne du group de l'aegyrine est rouvé dans un schiste metamorphique. 
Polycandros, Greece, the minerals become known as one of the constituent minerals of several metamorphic rocks. Thenceforth aegirite bearing schists or gneisses have been recorded from time to time from several places, though their occurrence are by no means common, and it is indeed the first time to find a similar rock in Japan, the sample now at my disposal being a unique one.

It is interesting that similar aegirite bearing siliceous metamorphics are found also in two other circum-Pacific regions, Java and South California, and these rocks have a close analogy in their petrological properties to that from Teshio. According to G. Niethammer, ${ }^{1)}$ the rock from Java is aegirite quartzite and was found as pebbles between Loh Kidang and Karang Samboeng. The rock from South California, reported by A.O. Woodford, ${ }^{2)}$ is quartz crossite garnet aegirite schist and was found as pebbles in a conglomerate, a member of the Lower Miocene Temblor Formation in San Onofre facies, exposed at the vicinity of San Onofre. In both cases, remarkably to say, that the pebbles of the aegirite bearing rocks are stated to be in association with other pebbles of various kinds of glaucophane rocks, just as in the case of Teshio.

5) In general, aegirite and aegirite-augite in metamorphic rocks, as in igneous rocks, are accompanied to soda-amphibole such as riebeckite and arfvedsonite, while they are intimately associated with glaucophane in the metamorphic rocks from the above mentioned circum-Pacific regions and also from Polycandros in Greece. ${ }^{3)}$ Nevertheless, there is no evidence of metamorphic transition between the two minerals, and their genetic relation is not clear in the section of the rock from Teshio examined by the present writer.

6) The aegirite-augite glaucophane quartz schist at the writer's disposal is a pebble found as float on the river-bed of the Obirashibe and nothing else is known about its derivation. By an inspection of various geological maps of Hokkaidô the writer was brought to the acquaintance of the fact that the entire drainage area of the river is occupied by Tertiary and Cretaceous sedimentaries, being quite free from any metamorphic rocks; it is therefore very likely that the pebble in question and likewise those of other glaucophane bearing schists are derived from a conglomerate in either of these older formations, in which they found their first site of repose.

1) G. Niethammer: Die Eruptivgesteine von Loh Oelo auf Java. Min-Petr. Mitt. (1909), 205.

2) A.O. Woodford: The San Onofre Breccia, its Nature and Origin. Bull. Depart. Geol. Sci. Univ. California, Vol. 15, No. 7, 1925, p. 197.

3) M.A. Lacroix : Op. cit. 